\title{
Chlamydia trachomatis OmcB protein is a surface- exposed glycosaminoglycan-dependent adhesin
}

\author{
Sanaa Fadel and Adrian Eley \\ Henry Wellcome Laboratories for Medical Research, Division of Genomic Medicine, \\ University of Sheffield Medical School, Beech Hill Road, Sheffield S10 2RX, UK
}

Correspondence

Adrian Eley

a.r.eley@sheffield.ac.uk

Received 27 June 2006

Accepted 30 August 2006

\section{INTRODUCTION}

In both industrialized and developing countries, Chlamydia trachomatis infection remains one of the most important sexually transmitted diseases. With approximately 90 million cases annually, infection with $C$. trachomatis is the most prevalent sexually transmitted bacterial disease in the world (Gonzales et al., 2004). As $70 \%$ of these infections are asymptomatic, they can cause major complications such as acute pelvic inflammatory disease, ectopic pregnancy, infertility or infant pneumonia if left untreated. This organism is also the agent of the blinding eye disease, trachoma, which currently affects about 150 million people worldwide (Mabey et al., 2003). Moreover, it is well established that $C$. trachomatis can cause conjunctivitis and pneumonitis in neonates and infants as a result of vertical transmission (Oroz et al., 2001). In addition, $C$. trachomatis has been found to be a likely risk factor for cervical cancer (Luostarinen et al., 2004).

As C. trachomatis is an obligate intracellular pathogen, it must initially attach to and enter the apical surfaces of epithelial host cells. Therefore, attachment to the host cell is the critical primary event for establishing an infection. A number of chlamydial ligands have been identified and characterized. These include the major outer membrane protein (MOMP) (Su et al., 1990; Swanson \& Kuo, 1994),

Abbreviations: COMC, chlamydial outer membrane complex; EB, elementary body; HS, heparan sulphate; MOMP, major outer membrane protein; MS/MS, mass spectrometry coupled to microcapillary liquid chromatography. heat-shock protein 70 (Raulston et al., 2002), the polymorphic outer membrane proteins and the thermolabile $34 \mathrm{kDa}$ membrane protein (Hackstadt, 1999), as well as OmcB (also known as Omp2) protein (Stephens et al., 2001), which remains controversial. Few epithelial plasma membrane components have been proposed as receptors (Vretou et al., 1989; Su et al., 1996; Mamelak et al., 2001; Fadel \& Eley, 2004).

OmcB is the second most abundant outer membrane protein in chlamydia. The $o m c B$ gene comprises $1641 \mathrm{bp}$ and encodes a protein of $60 \mathrm{kDa}$. The translated amino acid sequence reveals a relatively basic protein containing 24 cysteine residues (Allen \& Stephens, 1989). OmcB is highly conserved among chlamydia species (Newhall, 1987; Wagels et al., 1994) and has a biologically significant role as a structural protein; it is involved in the conversion of the replicating reticulate body to the infectious elementary body (EB) (Mygind et al., 1998) and is thought to contribute to cell-wall rigidity and osmotic stability of the EB (Newhall, 1987). Moreover, OmcB has been found to be a major immunogen in chlamydial infections (Mygind et al., 1998), inducing antibody responses in both humans and animals (Wagels et al., 1994). Not surprisingly, as it is a primary focus of the host immune response, $\mathrm{OmcB}$ is a potential candidate for a chlamydial vaccine (Eko et al., 2004; Penttilä et al., 2004).

There has been considerable debate regarding the precise localization and role of the $\mathrm{OmcB}$ protein in C. trachomatis adherence to host cells. Topological studies have indicated that OmcB is localized at the inner surface of the outer 
membrane (Everett \& Hatch, 1995; Mygind et al., 1998). It is thought not to be surface exposed (Watson et al., 1994; Everett \& Hatch, 1995), but it is considered to form a supramolecular lattice in the periplasm (Newhall, 1987; Sardinia et al., 1988). However, a few reports have suggested that it plays a role in attachment and invasion of the host cell (Ting et al., 1995; Stephens et al., 2001). For accurate characterization of the localization and adherence of $\mathrm{OmcB}$, it needs to be obtained free from other $C$. trachomatis proteins. However, the purification of antigens from $C$. trachomatis is very difficult, the main obstacles being its intracellular nature and the difficulty of cultivation of $C$. trachomatis in large quantities. Another complication is that even highly purified EB preparations are likely to contain damaged outer membrane fractions and unstable intermediate forms.

To overcome these obstacles, we isolated and sequenced the gene for this protein from C. trachomatis serovar LGV1 and cloned it into an Escherichia coli expression vector. The OmcB protein expressed in E. coli was used to define the location and the role in adherence of this highly debated $60 \mathrm{kDa}$ protein.

\section{METHODS}

Cloning of omcB. Template DNA for the PCR was obtained from C. trachomatis serovar LGV1, which had been cultured from EBs and purified according to the method of Caldwell et al. (1981). The primers used (MWG Biotech) were OMP-RBS-FOR (5'-ATAGAATTCGAATAGGAGATCCTATGAACA-3') and OMPHIS-STOP (5'-TCAGTGATGGTGATGGTGATGATAGATGTGTGTATTCTCTGTAT- $\left.3^{\prime}\right)$. These were used to amplify the entire $C$. trachomatis omcB gene, including the ribosome-binding site. Amplification was performed by PCR using 2.5 U Taq DNA polymerase of the Expand High Fidelity PCR system (Roche). The PCR product was cloned into the appropriate sites of the pJONEX4 vector (Sayers \& Eckstein, 1991), according to standard techniques (Sambrook et al., 1989), for expression of the OmcB protein under the control of the bacteriophage $\lambda \mathrm{P}_{\mathrm{L}}$ promoter. Protein expression from pJONEX4 was good. Therefore, the $o m c B$ gene was subcloned into the pET28a vector (Novagen), after digestion with the appropriate restriction enzymes. The ligation product was used to transform $\mathrm{DH} 5 \alpha$ E. coli cells. The colonies were screened for a plasmid containing the correct insert and this was used to transform BL21(DE3)RIPL E. coli cells by electroporation. This allowed protein expression from the T7 promoter. The construct $0 m c B-p E T 28$ was designed to produce full-length $\mathrm{OmcB}$ with a C-terminal His-tagged extension. The identity of positive clones was confirmed by nucleotide sequencing of the entire insert in both orientations.

Expression of OmcB protein. BL21(DE3)RIPL expressing the Cterminal His-tagged $\mathrm{OmcB}$ was grown to mid-stationary phase at $37^{\circ} \mathrm{C}$ in Luria-Bertani medium supplemented with $35 \mu \mathrm{g}$ chloramphenicol $\mathrm{ml}^{-1}, 25 \mu \mathrm{g}$ kanamycin $\mathrm{ml}^{-1}$ and $0.4 \%$ glucose. Expression was induced by adding $0.7 \mathrm{mM}$ IPTG followed by incubation overnight at room temperature in a rotary shaker. Cells were recovered by centrifugation at $13000 \mathrm{~g}$ for $20 \mathrm{~min}$ at $4{ }^{\circ} \mathrm{C}$ and frozen at $-80^{\circ} \mathrm{C}$. Proteins were examined from both the soluble fraction and the cell pellet. For large-scale purification, cells were grown in a 21 fermenter. The bacteria were lysed and solubilized under denaturing conditions using $8 \mathrm{M}$ urea in the presence of $2 \mathrm{mM}$ DTT. The protein was purified using the QIAexpress purification method according to the manufacturer's instructions (Qiagen). Eluate fractions were collected and analysed for the $60 \mathrm{kDa} O \mathrm{mcB}$ protein. The expressed protein was detected and identified by immunoblotting using a commercial anti-C. trachomatis antibody (Biogenesis) and anti-His tag antibody (Amersham Biosciences), in addition to tandem mass spectrometry coupled to microcapillary liquid chromatography (MS/MS) analysis.

The eluted protein fractions were combined and extensively dialysed against low-salt buffer (20 mM potassium phosphate, $2 \mathrm{mM}$ EDTA, $10 \%$ glycerol, $10 \mathrm{mM}$ DTT, $100 \mathrm{mM} \mathrm{NaCl}, \mathrm{pH} \mathrm{7.4)}$ at room temperature. The soluble dialysate was further purified on a heparin column (HiTrap heparin HP column; Amersham Biosciences) using an automated gradient elution system (GradiFrac; Amersham Biosciences), followed by concentration of the protein solution using a Vivaspin concentrator with a $30 \mathrm{kDa}$ cut-off (Sartorius). The final protein concentration was determined using the Bradford assay (Bradford, 1976). The purified protein was stored at $-80^{\circ} \mathrm{C}$ in $20 \mathrm{mM}$ potassium phosphate buffer and $30 \%$ glycerol.

Production of rabbit anti-OmcB serum. Rabbits were immunized three times with $500 \mu \mathrm{g}$ each of the purified OmcB protein. For each rabbit, $500 \mu \mathrm{g}$ antigen in a maximum volume of $250 \mu \mathrm{l}$ neutral phosphate buffer was mixed with an equal volume of Freund's adjuvant. Immunization was as follows: a first injection with complete Freund's adjuvant, a second injection at day 22 with incomplete Freund's adjuvant and a third at day 43 with incomplete Freund's adjuvant. Sera were collected 10 days after the third injection and tested using immunoblotting. IgG was purified from the whole anti-OmcB serum by passage through a protein $\mathrm{G}$ column.

To determine the titre of the antiserum, the purified recombinant OmcB protein, as well as total proteins from purified C. trachomatis EBs and chlamydial outer membrane complex (COMC) preparations, were separated by SDS-PAGE and electroblotted on to nitrocellulose membranes as described by Towbin et al. (1979). The membranes were incubated for $2 \mathrm{~h}$ with sera from the immunized rabbits (diluted $1: 1000-1: 10000$ ), as well as with pre-immune sera, and then with a peroxidase-conjugated anti-rabbit IgG (diluted 1:3000; Sigma). After washing, blots were developed using 4-chloro-1-naphthol.

\section{Localization of OmcB protein on the surface of C. trachomatis and E. coli}

Proteinase lysis of the $E$. coli cell surface. The accessibility of $\mathrm{OmcB}$ to proteinase $\mathrm{K}$ was used to localize the recombinant protein to a specific cellular compartment of $E$. coli. The technique was essentially that used by Dascher et al. (1993) to study translocation of recombinant MOMP. OmcB protein was induced in E. coli containing the $o m c B-p E T 28$ plasmid. The cells were harvested by centrifugation and resuspended in buffer $\mathrm{S}[100 \mathrm{mM}$ Tris/ $\mathrm{HCl}(\mathrm{pH} 8.2)$, $0.05 \mathrm{M}$ sucrose, $5 \mathrm{mM}$ EDTA] plus $1 \mathrm{mg}$ lysozyme $\mathrm{ml}^{-1}$ to convert the cells to spheroplasts. After incubation on ice for $5 \mathrm{~min}$, conversion of the cells to spheroplasts was monitored by dark-field microscopy. $\mathrm{MgSO}_{4}$ (final concentration $18 \mathrm{mM}$ ) was added to stabilize the spheroplasts. These were then centrifuged for $40 \mathrm{~s}$ and the supernatant was taken as the periplasmic fraction. To remove any periplasmic proteins trapped in the pellet, the spheroplasts were resuspended in buffer $\mathrm{T}$ [50 mM Tris/ $\mathrm{HCl}(\mathrm{pH} 8.2), 0.25 \mathrm{M}$ sucrose, $10 \mathrm{mM} \mathrm{MgSO}_{4}$ ] and centrifuged a second time. The supernatant was discarded. Osmotic lysis was achieved by suspension of half of the spheroplasts in $0.5 \mathrm{ml} 50 \mathrm{mM} \mathrm{Tris} / \mathrm{HCl}(\mathrm{pH} 8.2)$ and $2.5 \mathrm{mM}$ EDTA. When the cells had been lysed, $\mathrm{MgSO}_{4}$ was added to a final concentration of $20 \mathrm{mM}$. Whole cells, spheroplasts and cell lysates were then suspended in buffer $\mathrm{T}$ and each was divided into two equal portions. The first portions served as controls and the second portions were treated with proteinase $\mathrm{K}$ (final concentration $25 \mu \mathrm{g} \mathrm{ml}^{-1}$ ). The suspensions were incubated on ice for $20 \mathrm{~min}$, 
after which the protease inhibitor PMSF was added to a final concentration of $1 \mathrm{mM}$. Samples were analysed by SDS-PAGE and immunoblotted using an anti-Chlamydia antibody.

Infectivity inhibition assays using anti-OmcB serum. Inocula of C. trachomatis serovar LGV1 were adjusted so that not more than $\sim 50$ inclusions were present in each field at $\times 400$ magnification $\left(\sim 5 \times 10^{5}\right.$ infectious units) in $100 \mu \mathrm{l}$ PBS. The inocula were mixed with serial dilutions of the purified IgG of anti-OmcB serum $(1: 10-1: 500)$. Inocula mixed with pre-immune serum and inocula without serum were used as negative controls. Anti-Chlamydia antibody was used as a positive control. These were incubated for $1 \mathrm{~h}$ at $37^{\circ} \mathrm{C}$ and then used to infect confluent HeLa and Hec1B cell monolayers in 24-well tissue culture trays. The cells were incubated for $1 \mathrm{~h}$ at $37^{\circ} \mathrm{C}$ in $5 \% \mathrm{CO}_{2}$ and then washed with PBS three times before adding $1 \mathrm{ml}$ tissue culture medium supplemented with cycloheximide $\left(2 \mu \mathrm{g} \mathrm{ml}^{-1}\right)$ to each well. After incubation at $37^{\circ} \mathrm{C}$ in $5 \%$ $\mathrm{CO}_{2}$ for $48 \mathrm{~h}$, infected monolayers were fixed, stained and counted by direct immunofluorescence microscopy using the $C$. trachomatis culture confirmation test (Trinity Biotech).

\section{Examination of the binding of recombinant OmcB to eukaryotic cells}

Adherence assay. The method used was similar to that of Thornley et al. (1996). E. coli cells containing the omcB-pET28 plasmid were induced to produce $\mathrm{OmcB}$ protein and harvested by centrifugation, washed twice with PBS ( $\mathrm{pH}$ 7.4) and resuspended in an appropriate amount of Eagle's minimal essential medium. One millilitre of this bacterial suspension $\left(\mathrm{OD}_{600} 0.14\right)$ was inoculated on to HeLa and $\mathrm{Hec} 1 \mathrm{~B}$ cell monolayers and incubated for $90 \mathrm{~min}$ at $37^{\circ} \mathrm{C}$ with $5 \%$ $\mathrm{CO}_{2}$. After incubation, non-adherent bacteria were removed by washing three times with PBS. The cell layer and adherent bacteria were then fixed with a $90 \%$ methanol/acetic acid solution $(3: 1)$ for 5 min. After washing with distilled water, the remaining cells were stained with $10 \%$ Giemsa for 20 min, mounted and viewed by light microscopy. Negative controls included BL21 cells and BL21 containing pET28 vector (with no insert), in addition to BL21 expressing a periplasmic protein, ComH. The $c o m H$-pET28 plasmid was a kind gift of K. Kositidis (University of Sheffield, UK). To check that the binding of $\mathrm{OmcB}$ to $\mathrm{HeLa} / \mathrm{Hec} 1 \mathrm{~B}$ cells was specific, it was examined in the presence of anti-OmcB serum.

Examination of binding of $E$. coli producing OmcB to GAG-deficient cells. The degree of adherence was compared for GAG-deficient ( $p g s \mathrm{~A}-745$ and $p g s \mathrm{D}-677)$ and wild-type (CHO-K1) cells to evaluate the importance of host-cell GAGs for OmcB binding. Cell monolayers were grown to semi-confluence in 24-well tissue culture trays on sterile coverslips. The production of $\mathrm{OmcB}$ was induced from E. coli containing the $o m c B$-pET28 plasmid. The bacterial suspension $\left(\mathrm{OD}_{600} 0.14\right)$ was inoculated on to the cell monolayers and incubated for $90 \mathrm{~min}$ at $37^{\circ} \mathrm{C}$ with $5 \% \mathrm{CO}_{2}$ and the adherence assay was completed as described above, using the same controls.

Infectivity inhibition assays using recombinant OmcB. Confluent HeLa and Hec1B cell monolayers were prepared and subsequently infected with serovar LGV1 inoculum in $100 \mu \mathrm{l}$ PBS. Inocula were supplemented with serial dilutions of the purified recombinant OmcB and the assay was completed as described above.

\section{RESULTS}

\section{Expression of OmcB protein in E. coli}

OmcB protein could be expressed as a full-length $65 \mathrm{kDa}$ protein using pET28 vector, in the His-tagged form.
Expression of OmcB caused a reduction in E. coli cell viability, similar to that caused by expression of ComH protein (data not shown). Anti-C. trachomatis antibody was used for identification of the expressed protein. In addition, protein sequence obtained from MS/MS analysis confirmed the identity of the recombinant protein.

OmcB was purified using Ni-NTA agarose, which bound the six-His tag at the $\mathrm{C}$ terminus of the recombinant protein. The protein was refolded and concentrated using extensive dialysis and a heparin column. Anti-OmcB serum prepared by immunizing rabbits with the purified protein preparation reacted in Western blots at a high dilution $(1: 10000)$ with the C. trachomatis EBs separated by SDS-PAGE, as well as with the recombinant protein preparation. Immunoblot analysis confirmed the specificity of this serum for $\mathrm{OmcB}$ with no detectable cross-reactivity with other COMC proteins (Fig. 1). Both single and double bands of OmcB could be seen, which depended on dialysis and refolding of the denatured purified protein.

\section{Localization of OmcB protein on the surface of C. trachomatis and E. coli}

Proteinase lysis of the $E$. coli cell surface. Cellular localization of recombinant $\mathrm{OmcB}$ expressed in E. coli was assessed by proteinase digestion. This technique relies on the selective susceptibility to proteinase $\mathrm{K}$ digestion of surface-exposed proteins in whole intact cells and of periplasmic and inner membrane proteins in spheroplasts. E. coli was induced to express $\mathrm{OmcB}$ and then converted to spheroplasts using a brief lysozyme treatment to allow access to the periplasmic space.

Spheroplasts treated with proteinase K showed a complete loss of the recombinant OmcB, whilst intact E. coli cells showed that only part of the $\mathrm{OmcB}$ protein was digested (Fig. 2). This suggested that part of the $\mathrm{OmcB}$ protein is

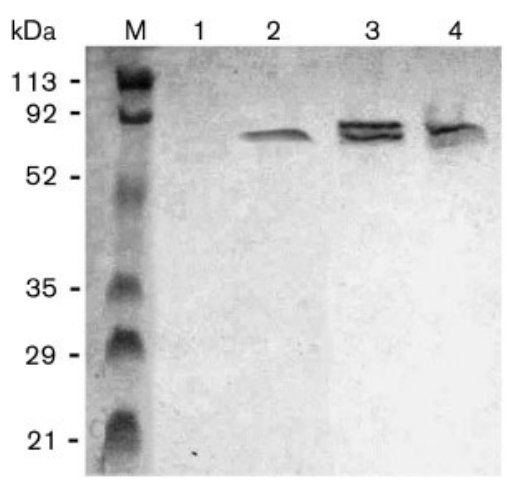

Fig. 1. Detection of $\mathrm{OmcB}$ protein by immunoblotting using anti-OmcB serum (diluted 1:10000). Lanes: 1, cell lysate of $E$. coli without the omcB insert; 2, E. coli lysate expressing OmcB protein; 3, purified recombinant OmcB protein; 4, COMC prepared from C. trachomatis serovar LGV1. M, Low-range protein marker. 


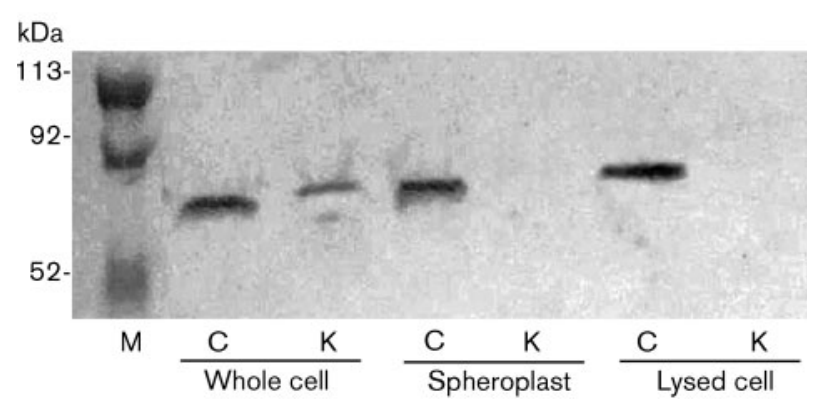

Fig. 2. Proteinase $\mathrm{K}$ digestion of intact cells, spheroplasts and the cytoplasmic fraction of $E$. coli expressing OmcB protein. Lanes contained controls (C) or cell extract lysed with $25 \mu \mathrm{g}$ proteinase $\mathrm{K} \mathrm{ml}^{-1}$ for $20 \mathrm{~min}$ on ice $(\mathrm{K})$ after which the protease inhibitor PMSF was added to stop the reaction. All cell fractions were resolved on SDS-PAGE and OmcB was detected by immunoblotting using anti-OmcB serum. M, Lowrange protein marker.

located on the outer membrane, whilst the remainder is not. Immunoblot analysis of the periplasmic fraction indicated the presence of $\mathrm{OmcB}$, suggesting that some of the protein might be located in the periplasmic space.

Infectivity inhibition assays using anti-OmcB serum. Fig. 3 shows the results of infectivity inhibition experiments in which chlamydial EBs were incubated with anti$\mathrm{OmcB}$ serum and then used to infect $\mathrm{HeLa}$ or Hec1B cells. Anti-OmcB was found to have an inhibitory effect on infectivity, which was statistically significant. Using a 1:100 dilution showed 39 and $36 \%$ inhibition using HeLa cells and Hec1B cells, respectively. Using a lower dilution did not lead to further inhibition of infectivity. For comparison, anti-Chlamydia antibody, which is immunogenic to all antigens of the EB, was used as a control.

\section{Examination of the binding of recombinant OmcB to eukaryotic cells}

Adherence assay. Binding was calculated on the basis of the number of adherent $E$. coli retained on the cell monolayer after washing. The mean number of adherent E. coli cells was counted per tissue culture cell and compared with the control. Fig. 4(a) shows that there was strong binding of E. coli cells expressing OmcB protein to HeLa cells. The HeLa cells showed stronger binding to OmcB than Hec1B cells; the mean number of adherent bacteria was found to be 47 for HeLa cells, compared with 33 for Hec1B cells. The negative controls (E. coli alone, E. coli containing the vector only and E. coli expressing ComH protein) showed only low levels of binding (Fig. $4 \mathrm{~b}$ ).

In addition, we examined binding in the presence of antiOmcB serum to determine the specificity of OmcB in the adherence process. Fig. 5 shows that addition of anti-OmcB serum resulted in inhibition of binding of $\mathrm{OmcB}$ to the cells

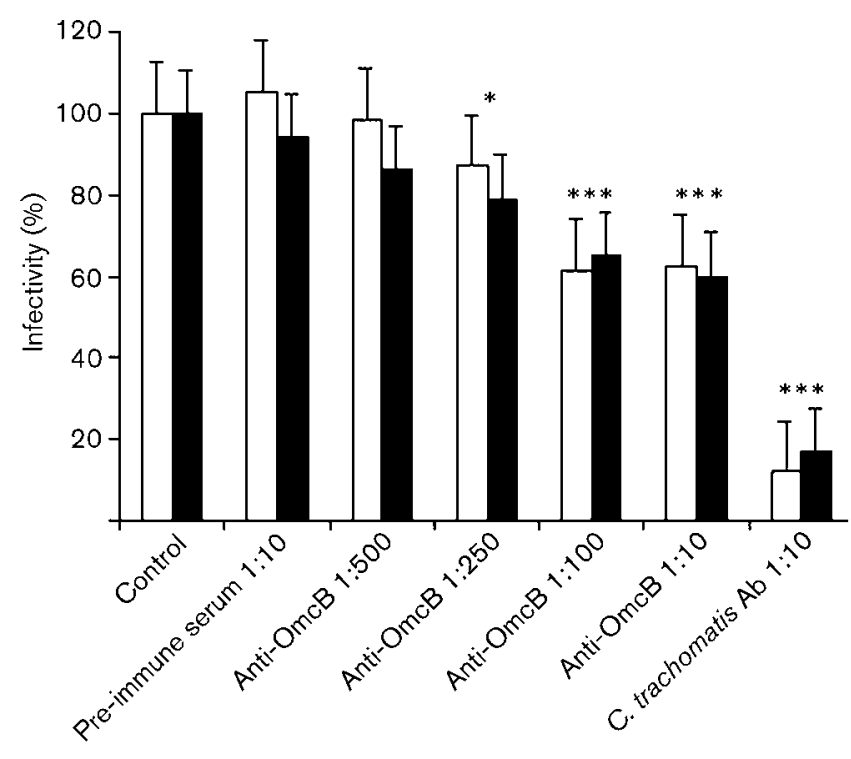

Fig. 3. Infectivity inhibition assay, using purified IgG from antiOmcB serum. Anti-Chlamydia antibody was used as a positive control. Pre-immune rabbit serum was used as a negative control. The figure represents the results of six different experiments, shown as means \pm SEM. Results were analysed statistically using a one-way paired ANOVA test. *, $P<0.05$; ${ }^{* \star *}, P<0.001$; white bars, HeLa cells; black bars, Hec1B cells.

by 68 and $76 \%$ to HeLa and Hec1B cells, respectively. Preimmune serum had no inhibitory effect on binding of $\mathrm{OmcB}$ to $\mathrm{HeLa} / \mathrm{Hec} 1 \mathrm{~B}$ cells when added in the same concentration as the anti-OmcB serum.

Examination of binding of $E$. coli expressing OmcB to GAG-deficient cells. Fig. 6 summarizes the results of adherence experiments in which the ability of E. coli producing OmcB to bind GAG-deficient $\mathrm{CHO}-\mathrm{K} 1$ cell lines was explored. The cell lines chosen were pgsA-745, deficient for all GAGs, and $p g s \mathrm{D}-677$, deficient for heparan sulphate (HS) but able to produce chondroitin sulphate, and each was compared with $\mathrm{CHO}-\mathrm{K} 1$ (wild-type) cells. The ability of serovar LGV to infect $p g s \mathrm{~A}-745$ and $p g s \mathrm{D}$ 677 cells was markedly reduced in comparison with that of the CHO-K1 wild-type cells. The negative controls showed only minimal binding to all of the cell lines tested.

Infectivity inhibition assays using recombinant OmcB. Fig. 7 shows the result of infectivity inhibition experiments in which chlamydial EBs were incubated with HeLa and $\mathrm{Hec} 1 \mathrm{~B}$ cells in the presence of various concentrations of purified recombinant $\mathrm{OmcB}$ protein. $\mathrm{OmcB}$ was found to have a significant inhibitory effect on the infectivity of serovar LGV1 of $C$. trachomatis. Inhibition was dose dependent and the maximum inhibition obtained was $70 \%$ at $150 \mu \mathrm{g} \mathrm{ml}^{-1}$. No significant difference was observed between the two cell lines. Purified ComH protein, when 


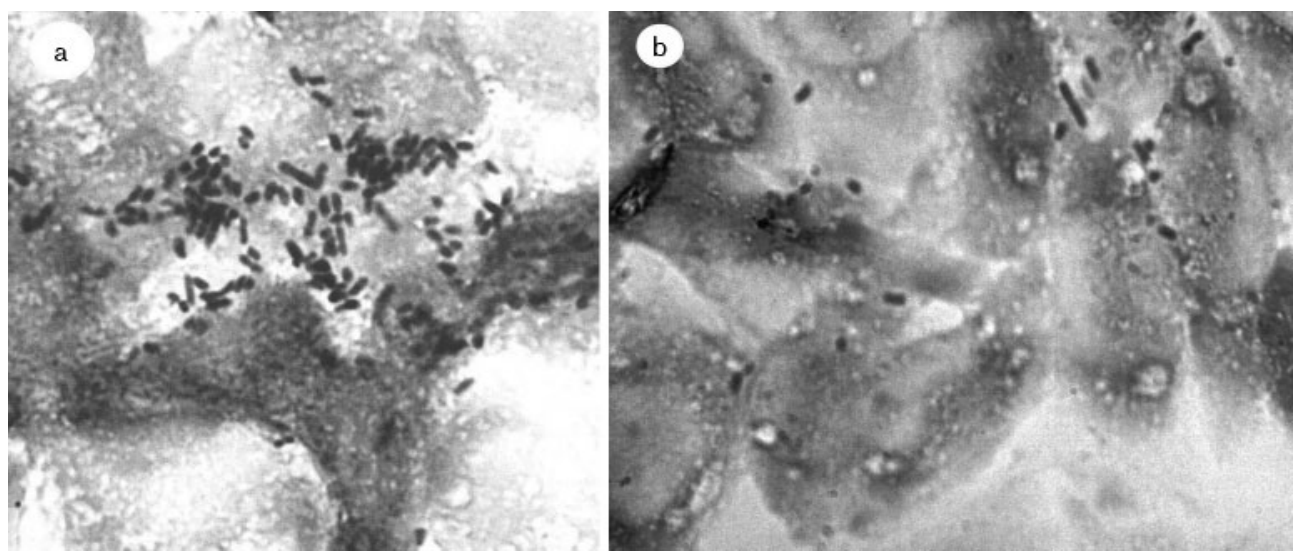

Fig. 4. Determination of the binding of recombinant OmcB to HeLa cells using an adherence assay. E. coli cells were incubated with HeLa cells for $90 \mathrm{~min}$ at $37^{\circ} \mathrm{C}$, followed by staining with $10 \%$ Giemsa stain: (a) E. coli cells induced to express OmcB protein, using $0.7 \mathrm{mM}$ IPTG overnight at room temperature, (b) E. coli cells expressing ComH protein, induced under the same conditions.

used at $150 \mu \mathrm{g} \mathrm{ml}^{-1}$, showed only minimal inhibition of infectivity.

\section{DISCUSSION}

Identification of surface components that mediate chlamydial attachment and the host cell receptors to which they bind is critical in understanding the pathogenesis of chlamydial infection. Studying the role of OmcB protein in chlamydial adherence to the host cell ideally necessitates evaluation of the whole protein purified from other chlamydial proteins. A good approach for this is expression

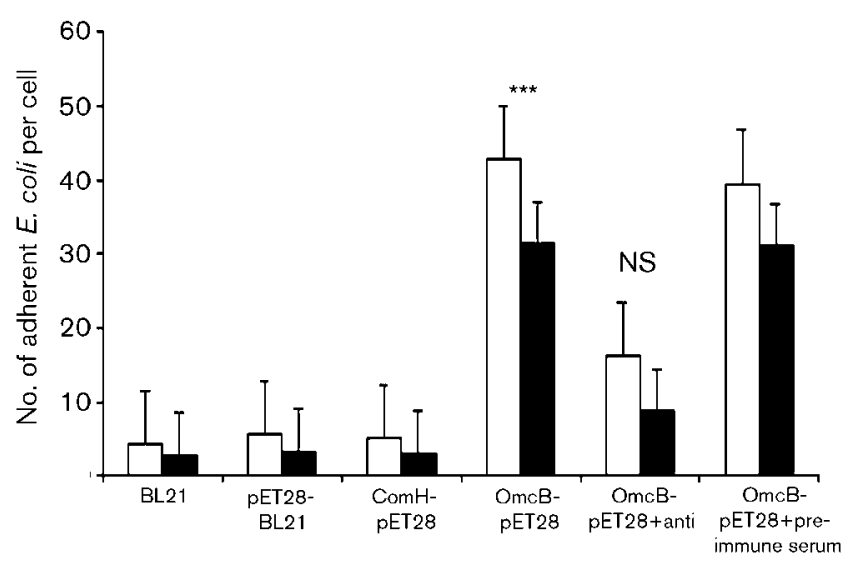

Fig. 5. Effect of addition of anti-OmcB serum on the adherence of $E$. coli expressing OmcB protein to HeLa (white bars) or Hec1B (black bars) cells. Negative controls included E. coli (BL21), E. coli with the vector only (pET28-BL21) and E. coli producing $\mathrm{ComH}$ protein (comH-pET28). The figure represents the results of six different experiments given as means \pm SEM. Results were analysed statistically using a one-way paired ANOVA test. ${ }^{* * *}, P<0.001$. NS, Not significant. of the protein in E. coli with subsequent evaluation of the translocation and function in an E. coli host in addition to the native chlamydia. Therefore, we cloned and expressed OmcB of C. trachomatis serovar LGV1 into an E. coli expression vector. Immunoblot analysis of the clones revealed a protein of approximately $65 \mathrm{kDa}$ and MS/MS analysis showed that the protein was processed correctly in the vector. To assess the cellular localization of $\mathrm{OmcB}$ in $C$. trachomatis and E. coli, two approaches were chosen:

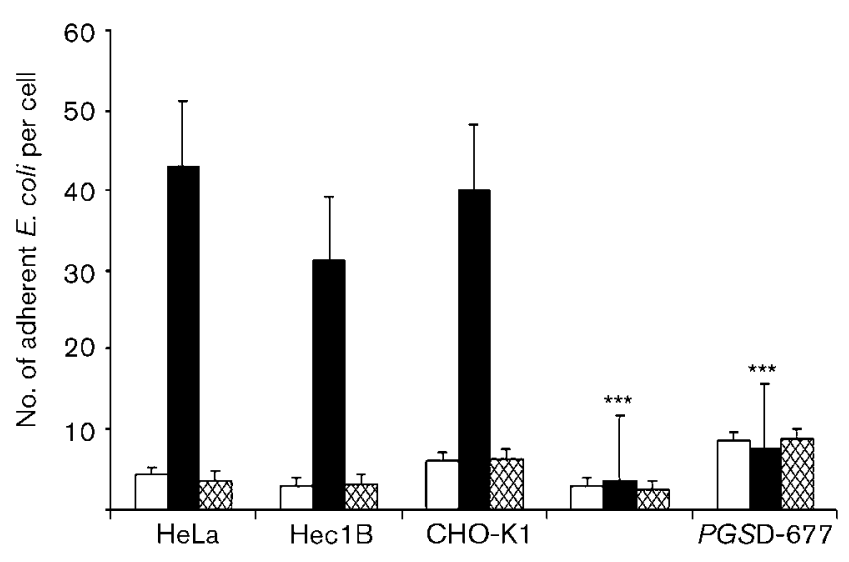

Fig. 6. Examination of the binding of $E$. coli only (BL21) (white bars), E. coli cells induced to produce OmcB protein (omcBpET28) (black bars) and E. coli cells induced to produce ComH protein (comH-pET28) (hatched bars) to GAG-deficient cells (pgsA-745 and pgsD-677), in comparison with wild-type $\mathrm{CHO}-\mathrm{K} 1$, HeLa and Hec1B cells, using $0.7 \mathrm{mM}$ IPTG overnight at room temperature. pgsA-745 and pgsD-677 cells are defective $\mathrm{CHO}-\mathrm{K} 1$ cell lines. The figure represents the results of six different experiments given as means \pm SEM. Results were analysed statistically using a one-way paired ANOVA test. ${ }^{\star \star \star}$, $P<0.001$. 


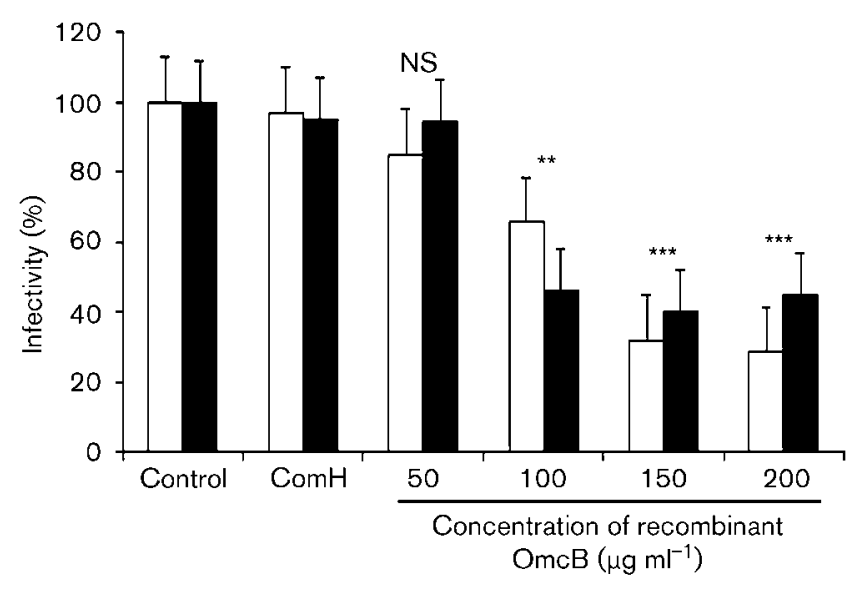

Fig. 7. Infectivity inhibition assay of C. trachomatis serovar LGV1 in the presence of recombinant OmcB protein. The assay was performed using HeLa (white bars) and Hec1B (black bars) cells. As an additional negative control, ComH was added at a concentration of $150 \mu \mathrm{g} \mathrm{ml}^{-1}$. This figure represents the results of six different experiments, given as means \pm SEM. Results were analysed statistically using a one-way paired ANOVA test. ${ }^{* *}, P<0.01 ;{ }^{* * *}, P<0.001$.

proteinase lysis of the cell compartments and an infectivity inhibition assay using anti-OmcB serum.

Results of proteinase lysis suggested that part of the recombinant $\mathrm{OmcB}$ protein was located on the outer membrane of $E$. coli, with the remainder located in the periplasmic space. To investigate the cellular localization of OmcB on C. trachomatis, we utilized an in vitro infection inhibition assay, similar to that used by others (Chen \& Stephens, 1994; Herold et al., 1997). We used two different cell types to represent the variety of epithelium found in the human female reproductive tract. The cell lines HeLa and $\mathrm{Hec} 1 \mathrm{~B}$ are derived from the human cervix and endometrium, respectively. The use of anti-OmcB led to an inhibitory effect on the infectivity of serovar LGV1, indicating that $\mathrm{OmcB}$ was accessible on the surface of chlamydial EBs. Although the effect was not dramatic, which could be due to redundant chlamydial adhesions, inhibition was dose dependent and was statistically significant.

There is a certain amount of controversy surrounding $\mathrm{OmcB}$ localization. It has been suggested that $\mathrm{OmcB}$ is located exclusively within the periplasm and is not surface exposed (Everett \& Hatch, 1995). It has also been suggested that disulphide cross-linked polymers of $\mathrm{OmcB}$ are the functional equivalent of peptidoglycan in other Gram-negative bacteria, forming a disulphide cross-linked network with the periplasmic domains of OmcA and other membrane proteins, and that this may contribute to the considerable structural stability of EBs (Everett \& Hatch, 1995). These workers also demonstrated the sensitivity of $\mathrm{OmcB}$ to trypsin treatment of EBs for serovar L2. Nevertheless, they concluded that the OmcB protein was not surface exposed and was not localized to the outer membrane.
In contrast, Ting et al. (1995) found that OmcB of Chlamydia psittaci was also susceptible to trypsin digestion of EBs, and proposed that this protein may be surface exposed. Moreover, Mygind et al. (1998) attempted to resolve the question of surface localization of $\mathrm{OmcB}$ in $C$. trachomatis by immunoelectron microscopy using OmcBspecific antibodies, but, as in previous studies (Collett et al., 1989; Watson et al., 1994), were unable to demonstrate that OmcB was accessible to antibodies using intact EBs.

Our findings provide conclusive evidence for the suggestion that part of OmcB is surface exposed (Stephens et al., 2001). The previous failure of antibodies produced against the whole $\mathrm{OmcB}$ protein in binding intact EBs may be because of limited $\mathrm{OmcB}$ regions exposed on the surface or because these antibodies could not recognize the conformational epitopes of OmcB.

To examine the role of $\mathrm{OmcB}$ in adherence to host cells, anti-OmcB antibody was used to probe the recombinant protein in an adherence assay. E. coli cells expressing $\mathrm{OmcB}$ bound significantly to HeLa and Hec1B. Only minor binding was observed for $E$. coli not containing $o m c B$, showing that expression of $\mathrm{OmcB}$ enabled E. coli to adhere strongly to tissue culture cells. To establish that the decreased viability and cell lysis of E. coli expressing $\mathrm{OmcB}$ protein was not responsible for adherence, we used ComH, a periplasmic protein (Smeets et al., 2000), cloned using the same vector and expressed in the same E. coli strain, which also resulted in decreased viability of $E$. coli when expressed. ComH showed no adherence to either cell line. This is of particular note as ComH has a similar molecular mass and pI to $\mathrm{OmcB}$, which means that the use of ComH as a negative control limits the possibility of $\mathrm{OmcB}$ adhering via non-specific electrostatic effects. To confirm that binding of E. coli expressing $\mathrm{OmcB}$ protein was specific, anti-OmcB antibody was added to the cells. The inhibition effect showed that this binding was specific and $\mathrm{OmcB}$ dependent. These findings clearly support a role for OmcB in specific binding to eukaryotic cells.

In a previous study using outer membrane fractions of $C$. psittaci in host-cell binding assays, Ting et al. (1995) found that OmcB bound HeLa cells in a dose-dependent fashion. Furthermore, Stephens et al. (2001) reported that OmcB prepared from COMC of serovar L2 bound heparin in a heparin column, whilst MOMP did not.

In order to explore the role of GAGs of the host cells as receptors for $\mathrm{OmcB}$, we performed a second set of adherence assays using $\mathrm{CHO}$ cells known to be defective in key GAGrelated genes. This approach has been used previously by us and other workers (Zhang \& Stephens, 1992; Stephens et al., 2000; Taraktchoglou et al., 2001). For our experiments, we chose cell lines with clearly defined properties. pgsA-745 cells are defective in xylosyltransferase (the first sugar transfer in GAG chain synthesis) and therefore do not produce any GAGs (Esko et al., 1985). The cell line pgsD-677 lacks both $\mathrm{N}$-acetylglucosaminyltransferase and glucuronyltransferase 
activities required for synthesis of HS, but they do produce chondroitin sulphate (Lidholt et al., 1992). The results showed that E. coli expressing $\mathrm{OmcB}$ had a very low adherence to cells deficient in GAGs, especially those lacking HS (Fig. 6), in comparison with the wild-type CHO-K1 cells.

These results indicate that binding of $\mathrm{OmcB}$ to host cells is dependent on GAGs, and particularly on HS, and suggest that OmcB in serovar LGV1 uses host-cell GAGs to bind and infect cells. This approach is similar to the study by Su et al. (1996) who showed a marked reduction of binding of a recombinant MOMP to pgsA-745 and pgsD-677 cells. Our findings confirm other reports (Chen \& Stephens, 1994; Davis \& Wyrick, 1997; Taraktchoglou et al., 2001) that LGV infection is dependent on an HS-related mechanism. They also support the evidence that these GAGs are on host cells and not on the surface of Chlamydia (Taraktchoglou et al., 2001; Fadel \& Eley, 2004).

To evaluate further the role of $\mathrm{OmcB}$ as an adhesin of $C$. trachomatis, we carried out infectivity inhibition assays in the presence of recombinant $\mathrm{OmcB}$. The recombinant $\mathrm{OmcB}$ protein competed with the native $\mathrm{OmcB}$ of Chlamydia and led to a marked inhibition of infectivity (70\%), confirming that $\mathrm{OmcB}$ is an important chlamydial adhesin.

In conclusion, our experiments provide supportive evidence that $\mathrm{OmcB}$ protein is exposed on the surface of $C$. trachomatis and immunoaccessible to antibody binding. They also show that the recombinant $\mathrm{OmcB}$ protein is surface exposed in the E. coli host. We do not yet know whether the surface conformation and orientation of $\mathrm{OmcB}$ in E. coli are identical to those in native chlamydial EBs.

Our results also show that $\mathrm{OmcB}$ serves as an adhesin molecule for $C$. trachomatis and that it acts by binding a GAG-like compound(s), possibly HS. These conclusions are based on the observations that the recombinant $\mathrm{OmcB}$ bound specifically to HeLa and $\mathrm{Hec} 1 \mathrm{~B}$ cells, and that $\mathrm{OmcB}$ did not bind mutant cell lines deficient in GAGs. These findings support a role for $\mathrm{OmcB}$ in specific binding to eukaryotic cells, which in turn is responsible for mediating chlamydial infectivity.

\section{ACKNOWLEDGEMENTS}

We are grateful to Professor Jon Sayers of the University of Sheffield for his help and advice on protein expression and purification.

\section{REFERENCES}

Allen, J. E. \& Stephens, R. S. (1989). Identification by sequence analysis of two-site posttranslational processing of the cysteine-rich outer membrane protein 2 of Chlamydia trachomatis serovar L2. J Bacteriol 171, 285-291.

Bradford, M. M. (1976). A rapid and sensitive method for the quantitation of microgram quantities of protein utilizing the principle of protein-dye binding. Anal Biochem 72, 248-254.
Caldwell, H. D., Kromhout, J. \& Schachter, J. (1981). Purification and partial characterization of the major outer membrane protein of Chlamydia trachomatis. Infect Immun 31, 1161-1176.

Chen, J. C. \& Stephens, R. S. (1994). Trachoma and LGV biovars of Chlamydia trachomatis share the same glycosaminoglycan-dependent mechanism for infection of eukaryotic cells. Mol Microbiol 11, 501-507.

Collett, B. A., Newhall, W. J., Jersild, R. A., Jr \& Jones, R. B. (1989). Detection of surface-exposed epitopes on Chlamydia trachomatis by immune electron microscopy. J Gen Microbiol 135, 85-94.

Dascher, C., Roll, D. \& Bavoil, P. M. (1993). Expression and translocation of the chlamydial major outer membrane protein in Escherichia coli. Microb Pathog 15, 455-467.

Davis, C. H. \& Wyrick, P. B. (1997). Differences in the association of Chlamydia trachomatis serovar E and serovar L2 with epithelial cells in vitro may reflect biological differences in vivo. Infect Immun 65, 2914-2924.

Eko, F. O., He, Q., Brown, T., McMillan, L., Ifere, G. O., Ananaba, G. A., Lyn, D., Lubitz, W., Kellar, K. L. \& other authors (2004). A novel recombinant multisubunit vaccine against Chlamydia. J Immunol 173, 3375-3382.

Esko, J. D., Stewart, T. E. \& Taylor, W. H. (1985). Animal cell mutants defective in glycosaminoglycan biosynthesis. Proc Natl Acad Sci U S A 82, 3197-3201.

Everett, K. D. E. \& Hatch, T. P. (1995). Architecture of the cell envelope of Chlamydia psittaci 6BC. J Bacteriol 177, 877-882.

Fadel, S. \& Eley, A. (2004). Chlorate: a reversible inhibitor of proteoglycan sulphation in Chlamydia trachomatis-infected cells. J Med Microbiol 53, 93-95.

Gonzales, G. F., Muñoz, G., Sánchez, R., Henkel, R., Gallegos-Avila, G., Díaz-Gutierrez, O., Vigil, P., Vásquez, F., Kortebani, G. \& other authors (2004). Update on the impact of Chlamydia trachomatis infection on male fertility. Andrologia 36, 1-23.

Hackstadt, T. (1999). Cell biology. In Chlamydia: Intracellular Biology, Pathogenesis, and Immunity, pp. 101-138. Edited by R. S. Stephens. Washington, DC: American Society for Microbiology.

Herold, B. C., Siston, A., Bremer, J., Kirkpatrick, R., Wilbanks, G., Fugedi, P., Peto, C. \& Cooper, M. (1997). Sulfated carbohydrate compounds prevent microbial adherence by sexually transmitted disease pathogens. Antimicrob Agents Chemother 41, 2776-2780.

Lidholt, K., Weinke, J. L., Kiser, C. S., Lugemwa, F. N., Bame, K. J., Cheifetz, S., Massague, J., Lindahl, U. \& Esko, J. D. (1992). A single mutation affects both $\mathrm{N}$-acetylglucosaminyltransferase and glucuronosyltransferase activities in a Chinese hamster ovary cell mutant defective in heparan sulfate biosynthesis. Proc Natl Acad Sci U S A 89, 2267-2271.

Luostarinen, T., Lehtinen, M., Bjorge, T., Abeler, V., Hakama, M., Hallmans, G., Jellum, E., Koskela, P., Lenner, P. \& other authors (2004). Joint effects of different human papillomaviruses and Chlamydia trachomatis infections on risk of squamous cell carcinoma of the cervix uteri. Eur J Cancer 40, 1058-1065.

Mabey, D. C. W., Solomon, A. W. \& Foster, A. (2003). Trachoma. Lancet 362, 223-229.

Mamelak, D., Mylvaganam, M., Whetstone, H. Hartmann E., Lennarz, W., Wyrick, P. B., Raulston, J., Han, H. \& Hoffman, P. \& Lingwood C. A. (2001). Hsp70s contain a specific sulfogalactolipid binding site. Differential aglycone influence on sulfogalactosyl ceramide binding by recombinant prokaryotic and eukaryotic Hsp70 family members. Biochemistry 40, 3572-3582.

Mygind, P., Christiansen, G. \& Birkelund, S. (1998). Topological analysis of L2 outer membrane protein 2. J Bacteriol 180, 5784-5787.

Mygind, P., Christiansen, G., Persson, K. \& Birkelund, S. (1998). Analysis of the humoral immune response to Chlamydia outer membrane protein 2. Clin Diagn Lab Immunol 5, 313-318. 
Newhall, W. J. V. (1987). Biosynthesis and disulfide cross-linking of outer membrane components during the growth cycle of Chlamydia trachomatis. Infect Immun 55, 162-168.

Oroz, C., Porter-Boveri, K. A. \& Thompson, C. (2001). Chlamydial infections in children. Sex Transm Infect 77, 462.

Penttilä, T., Tammiruusu, A., Liljeström, P., Sarvas, M., Mäkela, P. H., Vuola, J. M. \& Puolakkainen, M. (2004). DNA immunization followed by a viral vector booster in a Chlamydia pneumoniae mouse model. Vaccine 22, 3386-3394.

Raulston, J. E., Davis, C. H., Paul, T. R., Hobbs, J. D. \& Wyrick, P. B. (2002). Surface accessibility of the 70-kilodalton Chlamydia trachomatis heat shock protein following reduction of outer membrane protein disulfide bonds. Infect Immun 70, 535-543.

Sambrook, J., Fritsch, E. F. \& Maniatis, T. (1989). Molecular Cloning: a Laboratory Manual, 2nd edn. Cold Spring Harbor, NY: Cold Spring Harbor Laboratory.

Sardinia, L. M., Segal, E. \& Ganem, D. (1988). Developmental regulation of the cysteine-rich outer-membrane proteins of murine Chlamydia trachomatis. J Gen Microbiol 134, 997-1004.

Sayers, J. R. \& Eckstein, F. (1991). A single-strand specific endonuclease activity copurifies with overexpressed T5 D15 exonuclease. Nucleic Acids Res 19, 4127-4132.

Smeets, L. C., Bijlsma, J. J. E., Boomkens, S. Y., VandenbrouckeGrauls, C. M. J. E. \& Kusters, J. G. (2000). comH, a novel gene essential for natural transformation of Helicobacter pylori. J Bacteriol 182, 3948-3954.

Stephens, R. S., Fawaz, F. S., Kennedy, K. A., Koshiyama, K., Nichols, B., van Ooij, C. \& Engel, J. N. (2000). Eukaryotic cell uptake of heparin-coated microspheres: a model of host cell invasion by Chlamydia trachomatis. Infect Immun 68, 1080-1085.

Stephens, R. S., Koshiyama, K., Lewis, E. \& Kubo, A. (2001). Heparin-binding outer membrane protein of chlamydiae. Mol Microbiol 40, 691-699.

Su, H., Watkins, N. G., Zhang, Y.-X. \& Caldwell, H. D. (1990). Chlamydia trachomatis - host cell interactions: role of the chlamydial major outer membrane protein as an adhesin. Infect Immun 58, 1017-1025.

Su, H., Raymond, L., Rockey, D. D., Fischer, E., Hackstadt, T. \& Caldwell, H. D. (1996). A recombinant Chlamydia trachomatis major outer membrane protein binds to heparan sulfate receptors on epithelial cells. Proc Natl Acad Sci U S A 93, 11143-11148.

Swanson, A. F. \& Kuo, C.-C. (1994). Binding of the glycan of the major outer membrane protein of Chlamydia trachomatis to HeLa cells. Infect Immun 62, 24-28.

Taraktchoglou, M., Pacey, A. A., Turnbull, J. E. \& Eley, A. (2001). Infectivity of Chlamydia trachomatis serovar LGV but not $\mathrm{E}$ is dependent on host cell heparan sulfate. Infect Immun 69, 968-976.

Thornley, J. P., Shaw, J. G., Gryllos, I. A. \& Eley, A. (1996). Adherence of Aeromonas caviae to human cell lines HEp-2 and Caco-2. J Med Microbiol 45, 445-451.

Ting, L. M., Hsia, R. C., Haidaris, C. G. \& Bavoil, P. M. (1995). Interaction of outer envelope proteins of Chlamydia psittaci GPIC with the HeLa cell surface. Infect Immun 63, 3600-3608.

Towbin, H., Staehelin, T. \& Gordon, J. (1979). Electrophoretic transfer of proteins from polyacrylamide gels to nitrocellulose sheets: procedure and some applications. Proc Natl Acad Sci U S A 76, 4350-4354.

Vretou, E., Goswami, P. C. \& Bose, S. K. (1989). Adherence of multiple serovars of Chlamydia trachomatis to a common receptor on HeLa and McCoy cells is mediated by thermolabile protein(s). J Gen Microbiol 135, 3229-3237.

Wagels, G., Rasmussen, S. \& Timms, P. (1994). Comparison of Chlamydia pneumoniae isolates by Western blot (immunoblot) analysis and DNA sequencing of the omp 2 gene. J Clin Microbiol 32, 2820-2823.

Watson, M. W., Lambden, P. R., Everson, J. S. \& Clarke, I. N. (1994). Immunoreactivity of the $60 \mathrm{kDa}$ cysteine-rich proteins of Chlamydia trachomatis, Chlamydia psittaci and Chlamydia pneumoniae expressed in Escherichia coli. Microbiology 140, 2003-2011.

Zhang, J. P. \& Stephens, R. S. (1992). Mechanism of Chlamydia trachomatis attachment to eukaryotic host cells. Cell 69, 861-869. 